\title{
Reconstruction of Judicial Review Arrangements for Regional Regulations in Indonesia
}

\author{
Desyanti $^{1} \quad$ Sudarsono $^{2} \quad$ Muchamad Ali Safa' $^{2}{ }^{3} \quad$ Tunggul Anshari Setia Negara ${ }^{3}$ \\ 1. Doctoral Program in Law, Faculty of Law, Universitas Brawijaya, Malang - Indonesia \\ 2. Professor, Lecturer Faculty of Law, Universitas Brawijaya, Malang - Indonesia \\ 3. Lecturer Faculty of Law, Universitas Brawijaya, Malang - Indonesia
}

\begin{abstract}
This article intends to analyze the reconstruction of judicial review arrangements for regional regulations in Indonesia. The judicial review authority in the Supreme Court has different characteristics from the judicial review in the Constitutional Court of the Constitutional Court. The difference is that the object being tested by the Supreme Court is only limited to statutory regulations under the law, while the constitutionality of the law is examined by the Constitutional Court. The research used is normative legal research with the the statutory approach and conceptual approach. The result of discussion is the reconstruction of the judicial review arrangement by the Supreme Court needs to be carried out to the expansion of the types of test rights owned by the Supreme Court which are not only limited to conducting material trials. Regulation of the Supreme Court Number 1 of 2011 concerning the Right to Material Testing needs to be amended immediately, especially in terms of giving the title because it narrows the authority possessed by the Supreme Court itself. The reconstruction includes preliminary examination and trial examination carried out in a trial open to the public, and the decision is read out in a plenary session open to the public.
\end{abstract}

Keywords: reconstruction; judicial review; regional regulations; Indonesia

DOI: $10.7176 / \mathrm{JLPG} / 113-02$

Publication date:September $30^{\text {th }} 2021$

\section{Introduction}

Within the framework of a unitary state, the implementation of regional autonomy is a logical consequence of efforts to accelerate the realization of community welfare. Regional autonomy is a bridge to the success of the state in governing, prospering, and prospering local people who are far from the central government. Regional autonomy is the implication of changing the paradigm of a centralized state to a decentralized concept of statehood. Regional autonomy as a means of shifting the direction of the democratic transition towards the realization of a strong and reliable democratic consolidation as mandated by the reform agenda (Hamidi, J., et.al., 2012).

This transition period from centralized to decentralized government requires every region at the provincial, regency/city level to implement regional autonomy as widely as possible. This policy of autonomy and decentralization is considered very important, especially to ensure that the national integration process can be maintained as well as possible (Hamidi, J., 2011).

In Indonesia, the granting of the widest possible autonomy to regions is carried out based on the principle of a unitary state. In a unitary state, sovereignty is only in the state government or national government and there is no sovereignty in the regions. Therefore, regardless of the extent of the autonomy granted to the regions, the final responsibility for administering regional government will remain with the central government.

Regional legal products, especially regional regulations (hereinafter abbreviated as Perda) are instruments that are an important part of efforts to accelerate the realization of community welfare in the regions. This is because Indonesia is a state of law and one of the countries that are very close to the civil law legal system, which of course uses written law or better known as "statutory regulations" as the main instrument. The rule of law provides an understanding that sovereignty or supreme power in the state is based on law, in the sense of legal ideals (rechtsidee) which contains the noble ideals of the Indonesian nation (Kansil, C.S.T, 1986). To realize the idea of a rule of law, an orderly order is needed in the field of forming laws and regulations. The orderly formation of laws and regulations must be initiated from the time of planning until their promulgation.

According to I Gde Pantja Astawa, the existence of regional regulations cannot be separated from regional autonomy, because regional regulations as instruments and products of regional law are inherent in the regional autonomy system. The essence of regional autonomy itself is independence (zelfstandigheid) and not a form of freedom of an independent government unit (onafhankelijkheid). This independence is the regional authority to make legal decisions in the form of statutory regulations which are then (among other things) given the name Local Refgulation (Astawa, I.G.P., 2008).

Given the importance of the position of Regional Regulations, as one type of legislation, Regional Regulations (Perda) need to get legal certainty to be tested. This is because the testing of statutory regulation is a form of control mechanism over a legal norm (legal norm control mechanism). According to Aan Eko Widiarto, 
the entire legal product must be a harmonious whole (because it is synchronous or consistent vertically and horizontally) both from the material aspect which includes legal principles/because it fulfills the principles of establishing good laws and regulations, and the principle of material content) and by the legal principle which is the legal background/reason/ratio from the formation of the law, the meaning (both explicit and implied meaning), to the use of terminology; as well as from a formal aspect where the method of preparation must be by the applicable provisions (Widiarto, A. E., 2019).

As a system, the law has many links with various aspects and even other systems in society. Law as a product must be able to create legal certainty for the community. Often the laws and regulations that are formed fail to provide legal certainty for the community, which in the end fails to create legal order in society (Widiarto, A. E., 2019).

The mechanism for controlling legal norms can be implemented through political supervision, administrative control, or legal (judicial) control (Asshiddiqie, J., 2006). There are three known legal norms in testing legal norms, namely normative decisions that regulate (regeling) and are general and abstract, normative decisions containing administrative determinations (beschikking) are individual and concrete norms, normative decisions that are judgmental are general and the abstract norm is called a verdict.

In this context, Jimly Asshidiqqie emphasized that general and abstract norms can only be monitored through court law with a judicial review mechanism (Asshiddiqie, J., 2006). In Indonesia, the authority to conduct a judicial review belongs to the Supreme Court (MA) and the Constitutional Court (MK).

There are differences in the characteristics of judicial review in the Supreme Court and in the Constitutional Court in terms of the object being tested and the use of test stones that are indeed by the authority granted by the 1945 Constitution. However, there are differences in practice, especially the application of formal and material types of testing, as well as trial technicalities with the use of the principle of audi et alteram partem of course raises questions.

Based on this understanding, the author has a hypothesis that the application of the trial, especially judicial review in the Supreme Court and the Constitutional Court is at least the same as some adjustments or applies mutatis mutandis, because, in the doctrine of constitutional law, the right to examine is distinguished from the right to formal examination and the right to examine material. In addition, the principle of audi et alteram partem is a general principle in the study of law, so the judicial review process in the Supreme Court which is only one-way and closed should not be carried out. Therefore, considering the importance of the position of Regional Regulations and the differences in judicial review practices in the Constitutional Court and Supreme Court, the author will research a paper entitled "Reconstruction of Judicial Review Arrangements of Regional Regulations in Indonesia".

\section{Legal Materials and Methods}

In this article, the research used is legal research with the type of doctrinal research. In essence, the basic problem of this research is about the regulation of judicial review of regional regulations in the current Indonesian legislation (ius constitutum) and laws aspired to in the future (ius constituendum). Substantially, the writing of this paper includes normative legal research, namely legal research conducted by examining legal materials (library studies) or secondary data. According to Soerjono Soekanto and Sri Mamudji, normative legal research includes research on legal principles, research on legal systematics, research on levels of vertical and horizontal synchronization, legal comparisons, and legal history (Soekanto, S. \& Mamudji, S., 1995). In writing this paper, the author uses a statute approach, a conceptual approach, and a comparative approach (Marzuki, P. M., 2005).

\subsection{Theory of Legislation}

Hans Kelsen divides the norm system into two important aspects, namely the static aspect (nomostatics) which sees actions governed by law, and dynamic (nomodynamic) aspects which see the laws governing certain actions (Fadli, M., 2011). Maria Farida Indrati explained that what Hans Kelsen meant about a static norm system is a system that looks at the content of norms. In a static norm system, a general norm can be drawn into specific norms (Indrati, M. F., 2007). The withdrawal of special norms from the general norms means that the general norms are broken down into specific norms in terms of their content. While the dynamic norm system (nomodynamic) is a norm system that looks at the enactment of a norm or the way it is formed or abolished. "Law is anything that has come about in the way constitution prescribes for the creation of law... According to this concept, law is something created by a certain process, and everything created in this way is law" (Kelsen, H., 2009)

\subsection{Theory of Judicial Review}

The term judicial review is a technical term typical of United States constitutional law which means the authority of the judiciary to overturn any government action that is contrary to the constitution (Barron, J. A., \& Thomas, 
C. S., 1986). Soepomo and Harun Alrasid, said that in the Netherlands the term judicial review is not known and only recognizes the term right to test (toetsingensrecht) (Efendi,J.,2016). Therefore, in practice, there is often the use of the terms constitutional review, judicial review, and the right to test (toetsingsrecht).

In this case, the conception of judicial review is present in a broader object framework, compared to the concept of constitutional review, which is only limited to constitutional review of a rule of law against the constitution, while judicial review has a broader objective of examination, it can involve the legality of regulations under the law. laws against laws, not just laws against the constitution. However, in terms of the examiner's subject, the meaning of judicial review has narrowed, because the judicial review can only be carried out through a judicial mechanism (judiciary), which is carried out by judges. Meanwhile, if the constitutional review is subject to review, it can be carried out by a court institution (judicial review), a legislative body (legislative review), an executive institution (executive review), or other institutions appointed to carry out this function. This granting of test rights is the meaning of toetsingsrecht. Judicial review only applies if the examination is carried out on general and abstract norms "a posterior," meaning that the legal norms have been promulgated by the legislators (Asshiddiqie, J., 2005).

\section{Result and Discussion}

The review conducted by the Supreme Court is different from the constitutional review conducted by the Constitutional Court. First, the object being tested is only limited to laws and regulations under the Act (judicial review of regulation). Meanwhile, the judicial review of the law is conducted by the Constitutional Court (Syahuri, T., et.al., 2014). Second, what the Supreme Court uses as a benchmark is the Law, not the 1945 Constitution. Therefore, it can be said that the judicial review on the legality of regulation is testing the legal norms carried out by the Supreme Court. constitutionality of law (judicial review on the constitutionality of law). The latter is also known as the constitutional review of the law (Syahuri, T., et.al., 2014).

Judicial review is intended to be one way to guarantee state rights that are owned by a citizen in a diametrical position with the power to make regulations. Testing by judges can be carried out in a formal institutional form and can also be in a substantial form. Regulation as an institution can be requested for review by a judge, and a judge can hear a judicial review case in a separate trial. This is the institutionally formal form. Meanwhile, there may also be testing carried out by judges indirectly in every procedure in court. In adjudicating any case, the judge may or may have the authority to override the enactment of regulation or not to enforce a certain regulation, either in whole (total) or in part. Such a mechanism can also be referred to as a judicial review that is procedural, or a judicial review that is substantial (Asshiddiqie, J., 2005).

There are several legal problems with the procedural law of testing cases of testing legislation under the law. Therefore, it is important to arrange for judicial review of the Regional Regulation in the future, especially in terms of procedural law arrangements. There are several principles that the author will use to develop the material for the procedural law of the case testing of the legislation under the law, namely the principles in procedural law and the principles of establishing good laws and regulations.

Procedural law is a formal law that is essentially included in the scope of public law. In public law, formal law functions as a publiekrechtelijk instrumentarium to enforce material law (Effendi, M., 2014). Procedural law as formal law is a normative guide in bringing order and use of the judiciary.

\subsection{Reconstruction of Formal and Material Tests}

The importance of reconstructing the regulations for judicial review of regional regulations in the future arises from the differences in the application of judicial review trials in the Supreme Court and the Constitutional Court. There are at least two important distinguishing aspects, namely related to the application of material and formal types of testing, and the application of the principle of audi et alteram partem. In the Constitutional Court, judicial review can be carried out both materially and formally, as well as applying the principle of audi et alteram partem. Whereas in the Supreme Court it is different, in which a judicial review can only be carried out on material trials and the trial is carried out in private, in the sense that it does not go through the process of hearing the statements of the parties (audi et alteram partem). Therefore, the author tries to reconstruct the judicial review arrangement in the Supreme Court.

Historically, the regulation regarding the judicial review trial in the Supreme Court was regulated for the first time through Court Regulation Number 1 of 1993 concerning the Right to Judicial Review. The existence of this regulation is intended to regulate the law regarding the implementation of the judiciary regarding the Right to Material Examination. The issuance of Court Regulation Number 1 of 1993 concerning the Right to Material Examination is based on the provisions contained in Article 11 (4) of the MPR-RI Decree Number: III/MPR/1978; Article 26 of Law Number 14 of 1970; and Article 31 of Law Number 14 of 1985, which authorizes the Supreme Court to examine materially the laws and regulations under the Act.

The Court's Regulation Number 1 of 1993 concerning the Right to Judicial Review was later replaced with the Regulation of the Supreme Court Number 1 of 1999 concerning the Right of Material Testing and then in 
2004, it was replaced again with the Regulation of the Supreme Court Number 1 of 2004 concerning the Right to Material Testing. Finally, the regulation regarding the judicial review procedure in the Supreme Court is regulated in the Supreme Court Regulation Number 1 of 2011 concerning the Right to Judicial Review. In this context, the Supreme Court Regulation concerning the Right to Material Examination should be based on higher legislation, especially in terms of expanding the type of judicial review that can be carried out in the Supreme Court, namely the formal examination of statutory regulations under the law.

The expansion of this type of judicial review is important because if it refers to what is desired by the makers of the Constitution regarding the arrangement of judicial review in the Supreme Court, it is not in the sense that it is only a material test. Indeed, in the process of amending the 1945 Constitution, the mention of the right to test authority is often referred to as a judicial review. However, some mention complete material and formal tests. On the other hand, from the explanations of the experts who were invited in the process of discussing the amendments to the 1945 Constitution, it can be seen that there is an explanation regarding the judicial review which also includes material and formal tests.

The mention of the authority for only judicial review can be because in the history of judicial review arrangements in the Supreme Court, previously the Supreme Court was given the authority for judicial review. Thus, in terms of more terms, there are mentions of judicial review with the right to a judicial review. In this case, the author has the view that in the process of discussing the formulation of articles that regulate the judicial review authority by the Supreme Court, there is no clear statement that the judicial review authority by the Supreme Court only covers material trials and does not include formal tests. This is supported by the final result of the final formulation of Article 24A paragraph (1) which uses the phrase "... examines the legislation under the law against the law". In this context, the phrase "...testing the legislation under the law against the law" should not only be interpreted as a material review, but also a formal test of the legislation under the law against the law.

Furthermore, at the legal level, initially, the judicial review authority regulation in Law Number 14 of 1985 concerning the Supreme Court explicitly stated about the judicial review, namely "The Supreme Court has the authority to examine materially only on the laws and regulations under Constitution". However, along with the changes with the enactment of Law Number 5 of 2004 concerning Amendments to Law Number 14 of 1985 concerning the Supreme Court, there are differences in provisions, in which Law Number 5 of 2004 concerning Amendments to Law Number 14 of 1985 concerning the Supreme Court changed it to "The Supreme Court has the authority to examine statutory regulations under the law against the law". Indeed, in the Elucidation of Article 31 of Law Number 5 of 2004 concerning Amendments to Law Number 14 of 1985 concerning the Supreme Court, there is no further explanation with a "sufficiently clear" editorial. However, if it is related to the granting of judicial review authority in Law Number 48 of 2009 concerning Judicial Power, in the Elucidation in Article 20 paragraph (2) letter b it is expressly stated that the Supreme Court's right to test the legislation is lower than the law. The law can be carried out both on the content of paragraphs, articles, and/or parts of laws and regulations that are contrary to higher laws and regulations as well as on the formation of laws and regulations, namely as follows:

Article 20 paragraph (2) letter b:

The Supreme Court has the authority to examine statutory regulations under the law against the law. Elucidation of Article 20 paragraph (2) Letter b:

This provision regulates the Supreme Court's right to examine laws and regulations that are lower than the law. The right to test can be carried out both on the content of paragraphs, articles, and/or parts of laws and regulations that are contrary to higher laws and regulations as well as on the formation of laws and regulations.

Thus, of course, it is necessary to expand the types of test rights owned by the Supreme Court which are not only limited to conducting material tests. Regulation of the Supreme Court Number 1 of 2011 concerning the Right to Material Testing needs to be amended immediately, especially in terms of giving the title because it narrows the authority possessed by the Supreme Court itself. With the expansion of the types of test rights that are not only limited to material tests, then the Supreme Court is also expected to be able to formally examine the Perda in terms of the process of its formation. This is important, because not all legal products, especially Regional Regulations are formed by the procedures for establishing laws and regulations.

\subsection{Reconstruction of Examination Trial Arrangements}

The trial process by the Supreme Court is different from the practice of testing at the Constitutional Court, or the trial of cases of State Administration and State Administrative Court. The trial process by the Supreme Court was carried out openly so that the Petitioners did not know the testing process is carried out by the Supreme Court. In the absence of a trial title, the parties also cannot provide arguments to strengthen the petition or refute the petition, or present experts or witnesses for their statements to be heard. By not holding an open trial, the applicant cannot provide maximum arguments and convince the judge about the importance of the petition for 
testing.

Based on the provisions contained in Article 2 to Article 7 of the Supreme Court Regulation Number 1 of 2011 concerning the Right to Judicial Review, it can be seen that the judicial review mechanism by the Supreme Court is only carried out on the application file submitted by the Petitioner and the response file from the Respondent. Therefore, the Supreme Court conducts the Examination process without directly presenting the Petitioner/Respondent before the court, or in other words, the judicial review process in the Supreme Court is closed and only administrative. Notification of the contents of the decision is delivered by submitting or sending a copy of the Supreme Court's Decision to the parties without reading the contents of the decision in front of the Parties. Regional regulations are one of the main instruments for regions in carrying out regional governance, so transparency is needed in the cancellation process.

Based on Article 13 paragraph (1) of Law Number 48 of 2009 concerning Judicial Power, it is stated that "All court hearings are open to the public unless the law provides otherwise". The trial is open to the public so that the trial process can be followed by the public so that the judge in deciding the case will be objective based on the evidence and arguments presented in the trial. Through a trial that is open to the public, the public can also evaluate and ultimately accept the judge's decision. Several things that need to be regulated in the amendment to the Supreme Court Regulation Number 1 of 2011 concerning the Right to Test Materials include the following:

1. Preliminary examination is conducted in a session that is open to the public;

2. Examination of the trial is carried out in a trial which is open to the public, which includes: an examination of the principal application; examination of written evidence; listen to the statements of the parties; listen to witness testimony; listen to expert testimony; listen to the information of related parties; examination of a series of data, information, actions, conditions, and/or events by other evidence that can be used as instructions; examination of other evidence in the form of information that is spoken, sent, received, or stored electronically using optical or similar means.

3. The verdict is read/uttered in a plenary session open to the public.

\section{Conclusion}

Reconstruction of the judicial review arrangement by the Supreme Court needs to be carried out to the expansion of the types of test rights owned by the Supreme Court which are not only limited to conducting material trials. Regulation of the Supreme Court Number 1 of 2011 concerning the Right to Material Testing needs to be amended immediately, especially in terms of giving the title because it narrows the authority possessed by the Supreme Court itself. In addition, by the provisions in Article 13 paragraph (1) of Law Number 48 of 2009 concerning Judicial Power which states that "All court hearings are open to the public unless the law provides otherwise".

For this reason, the provisions of Articles 2 to 7 of the Supreme Court Regulation Number 1 of 2011 concerning the Right to Judicial Review which regulates the judicial review mechanism by the Supreme Court are only carried out on the application file submitted by the Petitioner and the response file from the Respondent without directly presenting the Petitioner/Respondent. Before the court, or in other words, the judicial review process in the Supreme Court is closed and only administrative and needs to be amended.

Several things that need to be regulated in the amendment to the Supreme Court Regulation Number 1 of 2011 concerning the Right to Material Testing are related to First, the preliminary examination is carried out in a trial which is open to the public; Second, the examination of the trial is carried out in a trial which is open to the public, which includes: an examination of the principal application; examination of written evidence; listen to the statements of the parties; listen to witness testimony; listen to expert testimony; listen to the information of related parties; examination of a series of data, information, actions, conditions, and/or events by other evidence that can be used as instructions; examination of other evidence in the form of information that is spoken, sent, received, or stored electronically using optical or similar means. Third, the verdict is read/uttered in a plenary session open to the public.

\section{Reference}

Asshiddiqie, J. 2005. Model-Model Pengujian Konstitusional di Berbagai Negara. Jakarta: Konstitusi Press Asshiddiqie, J. 2006. Perihal Undang-Undang. Jakarta: Konstitusi Press.

Astawa, I. G. P. 2008. Problematika Hukum Otonomi Daerah di Indonesia, Bandung: PT.Alumni.

Barron, J. A., \& Thomas, C. S. 1986. Constitutional Law. St. Paul Menn-West Publishing Co. C.S.T. Kansil. 1986. Pengantar Ilmu Hukum dan Tata Hukum Indonesia. Jakarta: Balai Pustaka. Efendi, J. 2016. Kamus Hukum Populer. Jakarta: Kencana. 
Fadli, M. 2011. Peraturan Delegasi Indonesia. Malang: UB Press.

Hamidi, J., et.al. 2012. Teori dan Hukum Perancangan Perda. Malang: UB Press.

Indrati, M. F. 2007. Ilmu Perundang-Undangan 1, Jenis, Fungsi, dan Materi Muatan. Jakarta: Kanisius.

Jazim Hamidi. Paradigma Baru Pembentukan dan Analisis Peraturan Daerah (Studi Atas Perda Pelayanan Publik dan Perda Keterbukaan Informasi Publik), Jurnal Hukum Ius Quia Iustum Law Journal of Islamic University of Indonesia No.3 Vol.18 Juli 2011 (336-363).

Kelsen $\mathrm{H}$ 2009.

Retrieved

from https://books.google.co.id/books?hl=id\&id=4dAr24lK4BEC\&q=124\#v=snippet\&q =124\&f=false

Marzuki, P. M. 2005. Penelitian Hukum. Jakarta: Prenada Media.

Soekanto, S. \& Mamudji, S. 1995. Penelitian Hukum Normatif, Suatu Tinjauan Singkat., Jakarta: Raja Grafindo Persada.

Syahuri, T., et.al. 2014. Problematika Pengujian Peraturan Perundang-undangan, Jakarta: Badan Pembinaan Hukum Nasional Kementrian Hukum dan HAM.

The 1945 Constitution of the Republic of Indonesia.

Widiarto, A. E. 2019. Implikasi Hukum Pengaturan Hukum Acara Mahkamah Konstitusi dalam Bentuk Peraturan Mahkamah Konstitusi, Jurnal Konstitusi, Volume 16, Nomor 1, Maret 2019. https://doi.org/10.31078/jk1612 